diseases receiving salicylate ${ }^{12-15}$. While short-term salicylate administration in man resulted in no increase in cortisol synthesis, prolonged administration was associated with a fall in cortisol turnover ${ }^{5}$.

The present acute experiments demonstrate no direct stimulatory influence of salicylate on adrenal cortisol secretion in the dog; in fact, the data may be interpreted as showing a modest suppression of cortisol secretion.

This work was supported in part by grants from the American Heart Association, the Life Insurance Fund, the National Institutes of Health and the New York Heart Association.

Richard S. Crampton* William C. BLack $\uparrow$ Arthur S. Verdesca RELJA I. NEDELJKOVIC James G. Hilton

Laboratory for Endocrine and Renal Physiology, Department of Medicine,

St. Luke's Hospital, New York 25.

* Trainee of the New York Heart Association (1960-61). t Fellow of the U.S. National Institutes of Health (1960-61)

Hailman, H. F., J. Clin. Endo. and Metab., 12, 454 (1952).

${ }^{2}$ Done, A. K., Ely, R., and Kelley, V., Metab., 7, 52 (1958).

${ }^{3}$ Smith, M. J. H., Ann. Rheum. Dis., 18, 298 (1959).

4 Batterman, R. C., Postgrad. Med., 25, 152 (1959).

Peterson, R. E., Black, R., and Bunim, J., Arthr. and Rheum., 1, 29 (1958).

- McClean, A. J., Ann. Surg., 88, 985 (1928).

${ }^{7}$ Hilton, J. G., Weaver, D., Muelheims, G., Glaviano, V., and Wegria, R., Amer. J. Physiol., 192, 525 (1958).

${ }^{8}$ Peterson, R. E., Karrer, A., and Guerra, S., Anal. Chem., 29, 144 (1957).

'Brody, B. B., Udenfriend, S., and Coburn, A., J. Pharm. and Exp. Therap., 80, 114 (1944).

${ }^{10}$ Cochran, J. B., Watson, R., and Reid, J., Brit. Med. J., ii, 1411 (1950).

${ }^{11}$ Van Cauwenberge, H., and Heughsem, C., Lancet, ii, 771 (1951).

${ }^{12}$ Smith, M. J. H., Gray, C., and Lunnon, J., Lancet, 1, 1008 (1954).

${ }^{13}$ Bayliss, R. I. S., and Steinbeck, A., Lancet, i, 1010 (1954).

" Herndon, R. F., Freeman, S., Wheeler, J., and Lestina, F., Amer. Med. Assoc. Arch. Int. Med., 101, 623 (1958).

is Ulloa, A., Gautney, M., Holley, H., and Hill, jun., S., Amer. Med. Assoc. Int. Med., 105, 914 (1960).

\section{Fate of Fructose in the Newly Delivered Fœtal Lamb}

Ir is well known that the blood of the foetal lamb contains a high concentration of fructose and that this disappears within a few hours of birth ${ }^{1-4}$, yet two recent publications have shown that the perfused liver of the foetal and new-born lamb is unable to metabolize fructose before the fifth day after birth ${ }^{5,6}$, and it is known that fructokinase is absent from the liver of the foetal lamb?. In view of these observations, the results of some preliminary experiments on the urinary excretion of fructose in newly delivered fotal lambs would appear to be of interest.

Six lambs weighing $3 \cdot 3-5 \cdot 4 \mathrm{kgm}$. were delivered by Cæsarean section under spinal anæsthesia from four cross-bred ewes at 138-141 days gestation age (term is about 147 days). Catheters were inserted under local anæsthesia into a femoral artery and into the bladder (via a small abdominal incision) of the foetus while it was still attached to the mother by the umbilical cord. Blood samples were taken and the bladder was emptied as completely as possible immediately before dividing the umbilical cord and at intervals during the next $6 \mathrm{hr}$. Blood and urine fructose was measured as described by Bacon and Bell'.

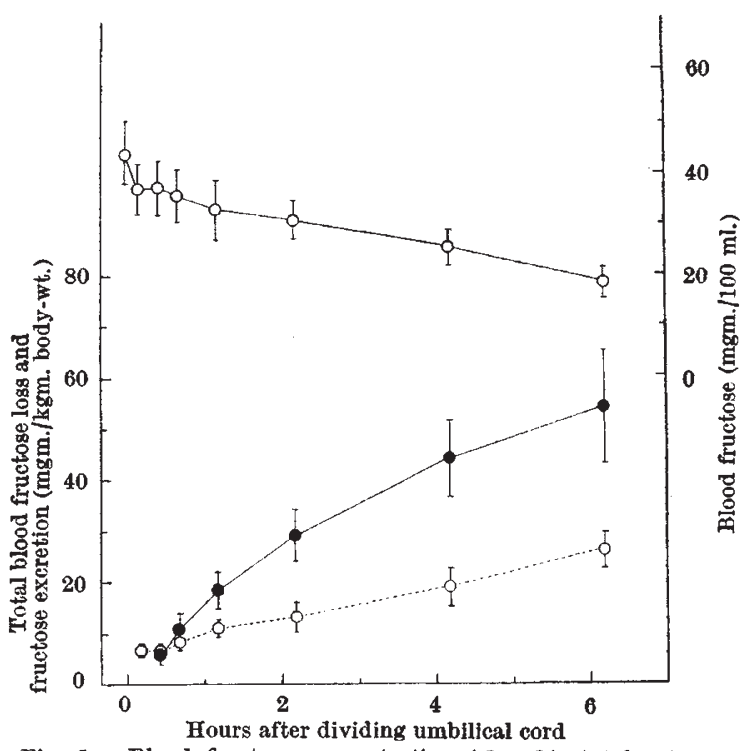
Fig. 1. Blood fructose concentration ( $\mathrm{O}-\mathrm{O})$, total urinary rom the blood $0 . . .0$ ) in newly delivered fotal lambs of 138-141 days gestation age. Means \pm standard error, 6 lambs

The results (means \pm standard error) are summar. ized in Fig. 1, which shows the blood fructose concentration, the total amount of fructose excreted in the urine, and the total amount of fructose disappearing from the blood at different time intervals after dividing the cord; this last was calculated on the generous assumption that the blood volume in $\mathrm{ml}$. was equiva. lent to 10 per cent of the body-weight in gm. There were considerable quantitative differences between individual lambs. Urine was excreted at a mean rate of $5.0 \pm 1.56 \mathrm{ml} . / \mathrm{kgm}$. $/ \mathrm{hr}$. over the first $6 \mathrm{hr}$. and the urinary fructose concentration varied from 42-1,536 $\mathrm{mgm} . / 100 \mathrm{ml}$. Nevertheless the results were wholly consistent. In each experiment, the amount of fructose excreted in the urine was more than sufficient to account for the apparent loss of fructose from the blood; indeed, as shown in Fig. 1, the mean rate of urinary fructose excretion was rather more than twice the apparent rate of fructose loss from the blood. Since the urinary fructose must have been derived mainly from the blood, this difference was presumably due to fructose passing from the tissues and/or extracellular fluid into the blood, so leading to a low estimate of blood fructose loss.

Until some estimate has been made of the total body fructose loss (and of the rate of fructose production), it is not possible to calculate the amount metabolized by the lambs. Nevertheless, as shown in the work on perfused livers ${ }^{5,6}$ these experiments suggest that the amount metabolized may be extremely small, and that in the prematurely delivered fotal lamb the urinary excretion of fructose probably accounts for the greater part, if not all, of the total fructose loss. While it has not yet been shown that this also applies to the fotal lamb in utero and to the new-born lamb delivered naturally, the available information on fotal urinary fructose excretion and on the rate of fall of blood fructose in normal new-born lambs suggests that they are similar to those observed in the present work. This would seem to suggest that fructose is of little importance as a source of energy to the fœtal and new-born lamb. However, Dickens and Greville ${ }^{8}$ have shown that, unlike other fœtal 
tissues, the foetal membranes of several species can utilize fructose almost as readily as glucose. Therefore, the possibility remains that the fructose of foetal ungulates, which have unusually low blood glucose concentrations ${ }^{4}$, may provide a source of energy for the amnion and allantois.

\section{Heather J. Shelley}

G. S. DAwES

Nuffield Institute for Medical Research, University of Oxford.

${ }^{1}$ Bacon, J. S. D., and Bell, D. J., Biochem. J., 42, 397 (1948).

${ }^{2}$ Hitchcock, M. W. S., J. Physiol., 108, 117 (1949).

Barklay, H., Haas, P., Huggett, A. St. G., King, G., and Rowley, D., J. Physiol., 109, 98 (1949).

shelley, H. J., J. Physiol., 153, 527 (1960).

s Andrews, W. H. H., Britton, H. G., Huggett, A. St. G., and Nixon, D. A., J. Physiol., 153, $199(1960)$.

${ }^{\circ}$ Andrews, W. H. H., Britton, H. G., and Nixon, D. A., Nature, 191, 1307 (1961).

${ }^{7}$ Hers, H. G., Biochem. J., 66, 30P (1957).

${ }^{\circ}$ Dickens, F., and Greville, G. D., Biochem. J., 26, 1251 (1932).

\section{PHARMACOLOGY}

\section{Effect of Drugs on the Uptake and Release of ${ }^{3} \mathrm{H}$-Norepinephrine in the Rat Heart}

Following the administration of a wide variety of drugs such as psychoactive agents (reserpine, chlorpromazine, imipramine), sympathomimetic amines (tyramine, amphetamine), cocaine, adrenergic blocking agents (phenoxybenzamine), and hypotensive drugs (guanethidine) a lower concentration of injected ${ }^{3} \mathrm{H}$-noradrenaline was found in the heart, spleen and adrenal glands ${ }^{1-3}$. Most of these drugs also increase the rate of metabolism of ${ }^{3} \mathrm{H}$-noradrenaline in the whole mouse presumably by preventing the protective binding of the hormone and exposing it to enzymatic attack ${ }^{4,5}$. Although these drugs have many actions, they could produce a common-end result by different mechanisms. They might lower the tissue levels of ${ }^{3} \mathrm{H}$-noradrenaline by blocking the entry of the circulating eatecholamine into the storage site, preventing the binding or causing the release of the bound ${ }^{3} \mathrm{H}$-noradrenaline or by a combination of these.

If a drug prevents the uptake, it should lower the tissue levels of ${ }^{3} \mathrm{H}$-noradrenaline only when given before the ${ }^{3} \mathrm{H}$-catecholamine. If it reduces the concentration when given after ${ }^{3} \mathrm{H}$-noradrenaline when the hormone is bound in tissues, then it releases the catecholamine. To distinguish between these actions rats were given drugs before or after the intravenous injection of ${ }^{3} \mathrm{H}$-noradrenaline and the amount of the ${ }^{3} \mathrm{H}$-catecholamine in the heart was measured.

Male rats (Sprague-Dawley), weighing from 160 $180 \mathrm{gm}$., received $10 \mu \mathrm{c} . / 100 \mathrm{gm}$. $d l-7-{ }^{8} \mathrm{H}$-noradrenaline $(20 \mathrm{mc} . / \mathrm{mgm}$.) in the tail vein. The rats were killed after 2,4 or $24 \mathrm{hr}$., and the hearts were homogenized with $12 \mathrm{ml}$. of ice-cold $0.4 \mathrm{~N}$ perchloric acid. After centrifugation the supernatant solution was assayed for ${ }^{8} \mathrm{H}$-noradrenaline ${ }^{6}$. Drugs were given before or after ${ }^{3} \mathrm{H}-$-noradrenaline as shown in Table 1. Rats were divided at random in groups of 6-12 for each drug treatment.

Reserpine, amphetamine, $d$-adrenaline and phenoxybenzamine reduced the amount of ${ }^{3} \mathrm{H}$-noradrenaline in the heart when given after as well as before the ${ }^{3} \mathrm{H}$-catecholamine (Table 1 ). Tyramine was previously shown to have this action?. It is concluded that these drugs release the bound hormone from its storage
Table 1. EFfect of DRUgS ON The UPtake AND Release OF II-NORADRENAIINE IN RAT HEART

$$
\begin{aligned}
& \text { Dose Time drug given } \begin{array}{c}
\text { Time rats } \\
\text { killed after }{ }^{8} \mathrm{H}-\text { Nor- }
\end{array} \\
& \text { (mgm.) before or after }{ }^{3} \mathrm{H} \text {-nor- adrenaline }
\end{aligned}
$$

Drug

None

Chlorpromazin

Chlorpromazine

None

hlorpromazine

None

Imipramine

Imipramine

Imipramine

None

Reserpine

Reserpine

None

$d$-Adrenaline

$d$-Adrenaline

d-Adrenaline

None

Phenoxybenzamine

Phenoxybenzamin

None

Dichloriso-

proterenol

Dichloriso-

proterenol

None

Amphetamine

mphetamine

$\overline{10} \quad 30 \mathrm{~min}$ before

. All drugs were given intramuscularly except $d$-adrenaline, which benzamine and dichlorisoproterenol and six for all other drugs. $* P<0.001$. $+P<0.01 . \pm P<0.05$.

site. The experimental technique does not distinguish whether or not these drugs may also inhibit the uptake of ${ }^{3} \mathrm{H}$-noradrenaline.

Treatment with chlorpromazine, imipramine and dichlorisoproterenol produced a lower concentration of ${ }^{3} \mathrm{H}$-noradrenaline when given before, but not after, the ${ }^{3} \mathrm{H}$-catecholamine (Table 1). Cocaine was previously shown to have this action?. From these observations, it appears that these drugs block the entry of ${ }^{3} \mathrm{H}$-noradrenaline into storage sites but do not cause its release.

Because chlorpromazine and imipramine blocked the uptake of ${ }^{3} \mathrm{H}$-noradrenaline, the ability of these drugs to block its release was examined. Previous studies have shown that monoamine oxidase inhibitors produce a higher concentration of ${ }^{3} \mathrm{H}$-noradrenaline in the rat after $24 \mathrm{hr}$. by preventing the spontaneous release of the hormone ${ }^{8}$. Chlorpromazine and imipramine did not appear to block the release of ${ }^{3} \mathrm{H}$-noradrenaline in $24 \mathrm{hr}$. (Table 1).

\section{JuLius AxELRoD Georg Hertting * LinCOLN PotTer}

Laboratory of Clinical Science,

National Institute of Mental Health, National Institutes of Health, Bethesda, Maryland.

* Present address: Department of Pharmacology, University of Vienna, Vienna.

1 Whitby, L. G., Hertting, G., and Axelrod, J., Nature, 187, 604 (1960).

'Axelrod, J., Whitby, L. G., and Hertting, G., Seience, 133, 383 (1961). $\mathrm{J}$

${ }^{3}$ Hertting, G., Axelrod, J., and Whitby, L. G., J. Pharmacol. Exp. Therap., 134, 146 (1961).

4 Axelrod, J., and Tomchick, R., Nature, 184, 2027 (1959).

5 Axelrod, J., and Tomchick, R., J. Pharmacol. Exp. Therap., 130, $367(1960)$.

6 Whitby, L. G., Axelrod, J., and Weil-Malherbe, H., J. Pharmacol. Exp. Therap., 132, 193 (1961).

Hertting, G., Axelrod, J., and Patriek, R. W., Biochem. Pharmacol. 8, 246 (1961).

${ }^{8}$ Axelrod, J., Hertting, G., and Patrick, R. W., J. Pharmacol. Exp. Therap., 134, 325 (1961). 